\title{
A Short Intellectual History of Problem-Based Learning
}

Virginie F. C. Servant-Miklos, Geoff R. Norman, and Henk G. Schmidt

\section{Introduction}

When the question of the origin of problem-based learning (PBL) arises in the literature, the consensus tends to be that the method was born at McMaster University in 1969, and that the ideas underpinning this program were in some way linked to the writings of the American philosopher John Dewey (Kolmos, Fink, \& Krogh, 2004; Schmidt, 1993). From there, speculations abound as to the specifics of the history of PBL, with some asserting that the American neurologist Howard Barrows was its originator (Hillen, Scherpbier, \& Wijnen, 2010), and others claiming a link to the Socratic Method described in Plato's Meno (Schmidt, 2012). In the contemporary turbulent context of higher education worldwide, some educators are prone to considering PBL as a panacea for all educational ills, while others vociferously resist its implementation. This sometimes leads to impassioned debates about the benefits or drawbacks of PBL at conferences, faculty boards, and in staff rooms that more resemble clashes of opposing political factions than reasoned educational arguments. To allow an informed debate about the ways in which PBL could serve education going forward, one must first understand where it came from; therefore, one must uncover its history.

In 2012, the authors undertook that task, using archival evidence collected from McMaster University, Maastricht University, and the two Danish Reformed Universities of Roskilde and Aalborg; oral history interviews from all four institutions and other institutions relevant to the early history of PBL; contemporary publications that indicate the development of thinking about PBL; and secondary sources reflecting on the history of PBL. These materials were processed using Whewell's inductive method of historical analysis (Whewell, 1858). This chapter summarizes the key findings of this 4-year research project to provide a broad overview of the history and development of PBL. 
For the purposes of this chapter, PBL can be defined as a pedagogical system used in tertiary education both undergraduate and graduate, particularly in medicine but also in fields as diverse as law, engineering, psychology, and liberal arts. The basic principles of this method are the use of realistic problems as the starting point of self-directed, small-group-based learning guided by a tutor who acts as a process guide rather than a point of knowledge transfer (Barrows \& Tamblyn, 1980). In PBL, students are expected to spend the majority of their time studying on their own or with their classmates rather than under the instruction of a teacher, which means that the use of lectures must be limited and access to quality learning resources guaranteed.

The history of PBL will be described in three parts: first, we shall look at the historical development of the first two PBL programs at McMaster and Maastricht. Second, we shall investigate the influence of educationally pioneering programs from both sides of the Atlantic on the development of PBL at these schools. Then, we shall expound the philosophical, intellectual, and psychological antecedents of the PBL through the authors and thinkers who inspired the founders of the method at McMaster and Maastricht. Finally, we shall provide an overview of further developments in PBL, including the case of the Aalborg University and its later adoption of the PBL appellation.

\section{The Early History of PBL: 1963-1980}

The first institution to use PBL was McMaster University in Canada, whose medical program opened its doors in September 1969. It was followed in 1974 by Maastricht University in The Netherlands. Although the latter imported the idea from the former, the programs were sufficiently different to warrant treating them as two iterations of PBL.

\section{McMaster's Pioneering Program in Medical Education}

Plans to open a Medical School in Hamilton, Ontario, were etched as early as 1963 by the reformist President of McMaster University Harry Thode (Thode, 1963). Thode himself did not have a specific idea of what this school should look like, only that it should be different. To enact this change, he appointed the young Dr. John Evans from the University of Toronto as its founding Dean. In 1966, before any work had commenced on the project, Evans sketched out the principles of PBL in a one-page memorandum more likely intended for his own use than as a mission statement for the school (Evans, 1966; Table 1.1 and Table 1.2).

By 1967, Evans had formed an Education Committee comprising four trusted colleagues to draw up a plan for the forthcoming MD program: Bill Spaulding, Fraser Mustard, Jim Anderson, and Bill Walsh. Spaulding, the Chair of the Committee and Associate Dean to Evans, was largely responsible for drawing up the organizational principles of the first PBL program (Spaulding, 1968) and presided over the implementation of committee decisions (Kraemer, 1968a); Anderson can be seen as the man behind its pedagogical principles (Barrows, 1996); 
Table 1.1 John Evans', 1966 General Objectives of the Faculty of Medicine

The Following is an outline of the objectives for the McMaster M.D. Program as expressed in terms of knowledge, abilities and attitudes that McMaster would like a graduate of the program to have acquired or developed:

1) The ability to identify and define health problems, and search for information to resolve or manage these problems.

2) Given a health problem, to examine the underlying physical or behavioral mechanisms.

3) The ability to recognize, maintain and develop personal characteristics and attitudes required for professional life [...].

4) The clinical skills and methods required to define and manage health problems of patients, including their physical, emotional and social aspects.

5) The ability to become a self-directed learner, recognizing personal education needs, selecting appropriate learning resources and evaluating progress.

6) To assess professional activity, both personal and that of other health professionals

7) To function as a productive member of a small group, which is engaged in learning, research or healthcare.

8) To be aware of and able to work in a variety of healthcare settings

Table 1.2 McMaster Program Outline (Spaulding, 1968)

Summer course: for those who are lacking in basic scientific knowledge. Consists in behavioral science, biochemistry and cell biology.

Phase I: Normal structure and function-14 weeks: "The approach will be predominantly regional. For example, as the student learns about the structure and function of the eye, he will also learn how the doctor examines the eye to test the integrity of the organ and its associated controlling structures and mechanisms."

Phase II: Abnormal Biological Mechanisms-6weeks

Phase III: Abnormal structure and Function-40 weeks. "This portion of the curriculum is organized by organ systems and includes relevant aspects of abnormal behavior, ethics, biomedical statistics and rehabilitation medicine." [...] "Each system will be studied by an integration of relevant anatomy, biochemistry, physiology, microbiology, pathology, pharmacology and epidemiology." Organ systems: hematopoietic, cardiovascular, respiratory, gastrointestinal, urinary and electrolytes, nervous, loco-motor, endocrine/ reproductive.

Horizontal program: $1 \mathrm{hr}$ per day in Phase I-III

Electives: $2 \times 6$ week periods after phase III: "In addition, students will be encouraged to approach faculty members with projects which are not in the electives list" (p. 6)

Clinical skills: 1 week. Just before the clerkship.

Phase IV: Clerkship-40 weeks

Mustard and Walsh, thanks to their connections and prestige as eminent scientists, were instrumental in ensuring that the program was accepted within the school and the community of Hamilton (Spaulding, 1991).

The Education Committee drafted a plan for a new medical program that turned medical education on its head, did away with tedious lectures, years of basic science before there was a patient in sight, and the silos of disciplines. Bound together in a so-called "matrix management" format (Spaulding, 1991), the disciplines at McMaster combined into study units based around organ 
systems. Within these units, students were introduced to the material through biomedical and clinical problems. These problems were tackled in small groups of four to six students, under the guidance of a tutor whose role was not to provide content but to guide the discussion (Ad Hoc Committee on Undergraduate Education, 1969). It is worth noting that the McMaster curriculum did not wholly ban lectures: they were recommended for exceptional circumstances, alongside a host of other educational tools such as field trips, guided instruction, or recitations (Educational Programme Committee, 1968). Another noteworthy point of the program was its aversion to summative assessment: students were not to be tested during their entire 3-year stay at the Faculty of Medicine but would face their judgment day when the time came to take their medical license (LMCC), an official state exam. Summative assessment was deemed to go against the very idea of $\mathrm{PBL}$, so tutors were asked to provide students with formative feedback - but the position of friend, guide, and evaluator proved to be very difficult for many tutors (Mueller, 2008) and the system eventually came to a grinding halt with high failure rates at the LMCC by the late 1980s, at which point summative examinations were introduced (Norman, Neville, Blake, \& Mueller, 2010).

In the beginning, few guidelines were issued on how this educational method would play out, spreading much confusion among the newly hired staff at McMaster (Kraemer, 1968b). In practice, different unit coordinators imagined different ways of implementing Spaulding's recommendations: some preferred short, experiential biomedical problems, others paper cases, and the neurologist Howard Barrows, who joined McMaster on sabbatical in 1968 and on a longterm contract in 1970, even introduced the idea that simulated patients and decks of cards (known as "problem-boxes") could be used as problems. Barrows had very little to do with the running of the first McMaster curriculum from 1969 to 1972, and contrarily to what is sometimes cited, did not invent PBL. He did, however, provide two lasting contributions: a method of training actors to behave like patients (Barrows \& Abrahamson, 1968), and a name for the founding fathers' brain child: problem-based learning, baptized in 1974 in an article published in the Journal of Medical Education (Barrows \& Neufeld, 1974). Barrows is perhaps best known for his book, Problem Based Learning, An Approach to Medical Education, written with Tamblyn in 1980. The overwhelming historical evidence, both oral and archival, suggests that the methods described in this book were an interpretation of PBL based on Barrows' focus on clinical reasoning skills and his work with simulated patients and problem-boxes rather than a reflection of the actual McMaster curriculum (Servant, 2016).

In 1969, McMaster admitted its first class of 20 students for a 3-year medical program. The program was divided up into four phases, all incorporating elements from basic and clinical sciences:

In this setup, a Horizontal Program was introduced to cater to McMaster's ambitions to provide Ontario with socially conscious and community-oriented physicians (Horizontal Programme Planning Committee, 1968). The plan was to pair up students and family physicians from the community to give the former an idea of the challenges facing the latter, as an ongoing program to run in parallel to the regular medical studies. In practice this plan fell through, and the 
Horizontal Program was rapidly discontinued. The rest of the setup remained roughly stable throughout the first curriculum of McMaster, which began in 1969 and was progressively dismantled after Evans' departure in 1972. As the old guard left and a new group of clinicians and managers such as Neufeld and Barrows came to the fore, their vision for PBL departed radically from the original views of the founding five, and must therefore be considered in its own capacity at the end of this chapter.

\section{Maastricht University Reinterprets PBL}

In 1970, an agreement was reached between the economically disadvantaged Dutch region of Limburg and the government, that a new medical school would be opened in the city of Maastricht on the condition that it provide something different to the existing seven medical schools in the country (Knegtmans, 1992). The desire to do something new was enshrined in the new faculty's Basic Philosophy (Basisfilosofie Achtste Medische Faculteit, 1972), but the exact shape of the curriculum to come remained to be seen. The newly appointed Dean Harmen Tiddens, a pediatric nephrologist, had befriended John Evans during a visit to the United States and organized for a Dutch governmental delegation to visit McMaster in May 1974 (Knegtmans, 1992). By the time the visitors returned, it was agreed that PBL would be the way forward for the new faculty. Tiddens had more of an external and political role as Dean and handed the development of the education program over to Wynand Wijnen, a psychologist.

The new medical school had to deal with students fresh out of high school rather than more mature students coming after a bachelor's degree; its program therefore had to be twice as long as McMaster's. Maastricht also did not have the LMCC to spur students to work and a reevaluation of the assessment policy was therefore necessary. To tackle these challenges, Maastricht endowed itself with a Department of Educational Research and Development from the start, headed by Wijnen and assisted by two young education researchers, Henk Schmidt and Peter Bouhuijs.

Thus, it became rapidly clear that Maastricht would offer a new interpretation of PBL. First, given the length of the program, the inexperience of the students, and the large number of students that was expected to go through Maastricht's door, the faculty had to structure the tutorial process in a more standardized manner than McMaster's ad hoc "leave-it-to-the-coordinator" policy. The first step was to institutionalize tutor and student training: after some trial and error, a training program was devised focusing on the simulation of likely situations in PBL classrooms rather than the popular "group dynamics" trainings that were all the rage in the 1970s (Schmidt, 1977a). Then, the tutorial itself had to be restructured to help students from high school cope with PBL. This challenge prompted Schmidt to devise in 1976 a systematic method for handling problems known as the Zevensprong (Seven Steps) (Schmidt, Majoor, \& Wijnen, 1979; Table 1.3).

The interpretation of the tutorial function was narrowed to a more processoriented role than it had been at McMaster, with a stricter enforcement of the "no-content expertise" rule. In practice, that did not mean that anybody could be 
Table 1.3 The Seven Step Method as Described by Schmidt in 1976, 1979

\begin{tabular}{ll}
\hline Step 1 & Clarify terms and concepts not readily comprehensible \\
Step 2 & Define the problem \\
Step 3 & Analyze the problem \\
Step 4 & $\begin{array}{l}\text { Make an inventory of the explanations inferred from step } \mathrm{n}^{\circ} \text { 3, proceeding } \\
\text { systematically }\end{array}$ \\
Step 5 & $\begin{array}{l}\text { Formulate learning objectives } \\
\text { Step } 6\end{array}$ \\
Step 7 & Sollect additional information outside the group \\
\hline
\end{tabular}

a tutor, but all members of the scientific staff, regardless of their medical background, could tutor any block (Projektgroep tutorensysteem, 1979).

Two of Maastricht's additional innovations were the invention of the Skillslab and the progress test. The Skillslab was a systematized way of imparting basic clinical skills to students. At McMaster, it had been assumed that students would pick these up along the way, at Maastricht however, a separate skills training program was planned from the beginning (Knegtmans, 1992). From 1977, the Skillslab became a co-curricular activity running alongside the PBL tutorials, with its own dedicated rooms where students could go at any time to practice their clinical skills on a set of anatomical models and mannequins. However, the supervised skills training sessions were as closely aligned with the concurrent PBL block as possible.

The progress test was the brainchild of Wijnen, whose particular field of expertise was in assessment. Based on the observation that end-of-block summative assessment pushed students to exam-oriented study behavior, Wijnen realized that such exams were not compatible with PBL (Wijnen, 1976). To remedy this problem, he incepted an assessment format whereby students of all years would be confronted with the same test comprising 250 true/false questions, administered four times a year-first-year students would be able to answer very little whereas final-year students would be expected to obtain a score of at least $70 \%$. This meant that students did not have to learn in any particular order, and that cramming information in before the test did not serve much purpose. This invention was so popular that, in the 2000s, it was extended to the majority of medical institutions in The Netherlands, and even eventually at McMaster.

Finally, Maastricht was the first institution to systematically investigate its own educational methods and, from 1977, produced a stream of publications under the authorship of Schmidt and Bouhuijs, sometimes seconded by Wijnen. These empirical studies, aimed at understanding the PBL process, were anchored in an ambitious research program proposed by the Department of Education Research and Development (Schmidt, 1977a). This yielded the book Onderwijs in Taakgerichte Groepen (Education in Task-Oriented Groups) (Schmidt \& Bouhuijs, 1980) at the same time as Barrows published his book, and by 1980s had enabled Schmidt to uncover the basic principles of cognitive psychology that underpin PBL's success as an education method (Schmidt, 1982). 


\section{Historical Influences on the Development of PBL}

The two PBL programs presented above did not develop in an educational vacuum: they were inspired by and drew from various educational institutions that proposed pioneering changes to pedagogy in the nineteenth and early twentieth century. These institutions included Harvard University, Western Reserve University (WRU) in the United States, and the so-called Oxbridge system in the United Kingdom. The way they practiced teaching and learning had a direct influence on the practice of PBL in its early years.

\section{The Harvard University Case Method}

It would be erroneous to speak of the Harvard Case Method as though it were singular and uniform. In fact, Kimball (1995) brought to light the existence of two Harvard Case Methods: the first, brainchild of Dean Christopher Columbus Langdell, was incepted in 1870 at the Law School (Garvin, 2003) and applied to the Medical School in 1900 (Cannon, 1900); the second, strongly inspired by the philosopher Dewey, was implemented at the Harvard Business School from the 1920s onwards (Fraser, 1931). The first method aimed to get students to reflect on cases by analogous reasoning, that is, by inducing general principles of law or medicine based on observations of a case as compared with another case. The second method was based on the use of real-life, open-ended business problems, the principles of which were harder to pinpoint and the solutions to which might be murkier than in the well-defined fields of law and medicine. While it was popular in legal education all over the United States, the use of the Case Method by analogy in medicine went by largely under the radar and by the 1920s had disappeared entirely. By contrast, the Case Method in business endured and became popular enough that, by the time McMaster was founded, it was a well-known educational innovation in North America (Kimball, 1995). The Case Method was introduced to McMaster through one of its founding fathers, Bill Spaulding, whose fraternity brother was a Harvard Business School alumnus (Spaulding, 1991): the practice of the Case Method at the Business School inspired Spaulding to devise a medical curriculum based on the use of problems.

There is however a notable difference between the case method as it was practiced at the Business School and PBL: whereas PBL students approached a new problem fresh and unprepared, with nothing but their prior knowledge to tackle what was at hand, Case Method students were required to prepare selected readings before attending a group discussion on the case (Fraser, 1931). Contrary to popular belief, the Case Method did not involve the mere application of information handed to students in lectures to practical cases for the sake of practice and elaboration. Students were expected to furnish the study effort on their own in both PBL and the Case Method-but the activation of prior knowledge through exploratory group discussion was absent from the Case Method, whereas it was a chief component of PBL. 


\section{The Western Reserve University School of Medicine Medical Education Experiment}

While PBL is most well-known for its use of problems as the starting point of learning, it also featured the integration of various disciplines in thematic units rather than parallel courses competing for students' attention at both McMaster and Maastricht. This idea was brought over to PBL from a little-known institution from Ohio: Western Reserve University School of Medicine (WRU).

In 1952, WRU reformed its medical curriculum under the leadership of Joseph Wearn and Hale Ham, both of whom either had direct experience of or close contact with the Harvard Medical School's experimentation with the Case Method (Williams, 1980). Although they preceded McMaster by two decades, the objectives of the reformed WRU program were very similar in their humanist, interdisciplinary, and antitraditionalist stance. WRU successfully put together the first interdisciplinary curriculum in medical education, guided by "subject committees" rather than the traditional hierarchy of departments. Originally, 14 subject committees focusing on various components of the human body were drawn up to organize the students' learning. Eventually, these were concentrated into five thematic study units based around organ systems, such as "cell biology" or "endocrine and reproductive systems." However, despite the inclusion of research projects, the WRU program still maintained traditional teaching methods as the basis of the learning process, with almost half of students' time allocated to lectures (Williams, 1980).

Spaulding visited WRU in 1967 in preparation for McMaster's opening (Spaulding, 1967), and borrowed their idea of thematic units organized around organ systems wholesale (McAuley, 1978). The system of organ-based learning units was transferred to Maastricht where they became known as "blocks" and applied across all 6 years of the medical program (Knegtmans, 1992). In addition, the idea was broadened to include new themes such as life phases or complaints as the basis for the blocks. A similar idea was later adopted by the Maastricht Law School (Cohen \& Crombag, 1978) and became a staple of PBL programs in multiple fields of study.

\section{The Oxbridge Tutorial System}

Oxbridge is a British contraction that refers to the two oldest universities in the country: Oxford and Cambridge. Over the many years of their existence, both institutions developed a mentorship role for teachers vis-à-vis their students known as a "tutor." During the nineteenth century, this role crystalized into a pedagogical function (Palfreyman, 2001). In addition to their lectures and private study, students were required to meet with their tutor once per week to present and discuss some of their written work (Moore, 1968). This tended to be a one-onone or one-on-two relationship, reminiscent of the interaction of Socrates with his pupils. The specifics of the tutorial process were left up to the tutor, but in no case should the tutor be lecturing or providing new information to the student: it was the student's obligation to study, and the tutor's job to question and probe. 
McMaster explicitly borrowed the term from Oxbridge (Mueller, 2008), as attested by the lengthy Education Committee debates on the subject (Kraemer, 1969a, 1969b). The inspiration was brought over the pond by British doctors hired to help start the McMaster program, and continued to hold sway over the description of the tutor role at McMaster, especially as more tutors came in who had themselves experienced the Oxbridge model (Dickinson, 1970). However, tutoring in PBL was done with small groups, rather than one-on-one; the mentorship aspect of the role was usually lacking, as tutors were instructed to serve as process guides on an equal footing with students rather than intellectual leaders of the group. Given this conception of the tutor, content expertise was deemed to interfere with the guidance role. This view of tutoring was advocated by PBL pioneer Jim Anderson, who argued that the Oxbridge model, taken wholesale, would be "too paternalistic for North American Universities in 1969" (Kraemer, 1969a, 1969b). Instead, he called for a system in which students should be exposed to as many teachers, disciplines, and professions as possible before choosing for themselves whether they wished to enter a mentoring role with one of them. The "tutor as a process guide" role was taken to its most advanced form at Maastricht University, where, in principle, any member of the faculty could tutor any problem, regardless of which disciplines the PBL block covered (Projektgroep tutorensysteem, 1979). This was later scaled back when evidence emerged that content expertise could be beneficial in tutoring (Schmidt, Arend, Moust, Kokx, \& Boon, 1993).

\section{Intellectual Influences Behind Central Concepts of PBL}

Where does one begin looking for the theoretical foundations of PBL? There are so many thinkers and educators whose ideas could be construed as related to the principles of PBL. How to choose the most relevant ideas without veering into broad generalizations that have very little to do with PBL? Our method involved parsing through historical materials and oral history interviews and picking out sources of inspiration that were explicitly mentioned, or concepts that were so clearly tied to a particular theorist that the latter's influence became apparent. By starting at the source, with the thoughts and writings of those who actually founded PBL, we pieced together its intellectual history in a manner faithful to the original ideas behind the method. This led us to uncover many sources of inspiration for McMaster, Maastricht, and other prominent PBL programs around the world. However, in the interest of conciseness, we have selected the most interesting for the purposes of this chapter: the Flexner Report (1910), the humanist psychology of Carl Rogers, the pragmatist philosophy of John Dewey, Karl Popper's philosophy of science, and the 1960-1970s debates within cognitive psychology.

\section{Abraham Flexner and Renewal in Medical Education}

The Flexner Report was a comprehensive survey of the state of medical education in North America in 1910, conducted under the auspices of the Carnegie Foundation by Abraham Flexner. Perhaps because Flexner himself was primarily 
an educator rather than a doctor, the recommendations in his report carried strong pedagogical undertones, simmering just beneath the surface of his critique of the poor quality of medical education in the United States in the early twentieth century. Flexner was strongly influenced by the sorts of ideas on experiential learning and "learning by doing" that were floating around at that time, particularly in circles associated with John Dewey (Ludmerer, 2010). His chief bone of contention was the outdated lecture-based mode of learning, railing against "huge, badly lighted amphitheaters" (Flexner, 1910, p. 9) and their nefarious effect on instruction. As an admirer of the burgeoning Harvard case-method of legal education, he saw the potential of more active ways of learning for medical education. In addition, Flexner saw the medical world evolving toward a more preventive and socially aware mode of operation and called upon medical education to follow suit, developing in future doctors the knowledge, skills, and techniques they would need to face the future. Finally, Flexner argued that the common division between basic and clinical sciences in the medical curriculum was detrimental to doctors in training, who should instead consider the hospital as their training ground and laboratory.

These ideas found a strong echo within the team who founded the McMaster curriculum, and particularly with John Evans, who made the development of knowledge, attitudes, and skills the priority of McMaster's curriculum (Evans, 1966), citing Flexner as his main source of inspiration some years later in a retrospective interview (McAuley, 1979). Flexner's commitment to joining basic and clinical sciences was seconded by Fraser Mustard, who spurred the development of the integrated practice of both through PBL at McMaster (Mustard, 1968). Further references to Flexner began to appear in the meetings of the Education Committee in charge of setting up and running the first PBL program in 1969, with particular emphasis on the Flexner Report's condemnation of teacher-driven instruction, and the distinction of research and teaching as two separate and often contradictory professions (Ad Hoc Committee on Undergraduate Education, 1969). Flexner's legacy on the McMaster program is poorly understood and very little mention is made of his report today, but it was to a significant extent his ideas on suppressing lecture-based education and learning basic sciences through clinical practice that gave rise to the use of clinical problems at McMaster.

\section{John Dewey and Experiential Learning}

When discussing the advent of the progressive education movement in the twentieth century, a reference to the American philosopher John Dewey is mandatory. Dewey was far more than an educationist: during his career, he penned 37 major works in education philosophy, psychology, and general philosophy (Apple \& Teitelbaum, 2001) and he is also known as the father of pragmatist philosophy and a prominent scholar within the functionalist school of thought (Hergenhahn, 2001). Dewey's work on education was twofold: first, from a psychological perspective, he attempted to understand learning as an experiential process that should connect with the person's lived experience; this is what is often referred 
to as "learning by doing." Experiential learning, for Dewey, should be triggered by a "problem," understood as an unclear situation or phenomenon in need of an explanation (Dewey, 1933). Then, the learner should use what he already knew about the world from his everyday experience to seek out a solution. In many senses, Dewey's conclusions on education foreshadowed the cognitive revolution in psychology, with its emphasis on the activation of prior knowledge and contextualization. From a philosophical perspective, his work comprised a societal project in which persons bound to their own educational experience would become the grounded citizens required by a democratic society (Dewey, 1916/2011).

Although Dewey's ideas were not taken wholesale by the founders of PBL, and he was scarcely mentioned in any of the early PBL programs, his influence came through at McMaster in two ways. Indirectly, Deweyan ideas came to PBL via the influence of the Harvard Business School and its use of the Case Method inspired by Dewey's "problem-method"; namely the use of open problems as the starting point for learning problem solving and from specific problems inducing general principles (Kimball, 1995). Therefore, by adopting some of the ideas of the Case Method, McMaster indirectly bought into the Deweyan philosophy. More directly, Dewey was cited in support of the PBL philosophy in a report on the McMaster MD program from 1969 (Ad Hoc Committee on Undergraduate Education, 1969), and in one of the early publications describing McMaster's PBL program, written by one of its founding members Dr. John Hamilton (1976). Dewey also found favor with some of the theoretical architects of the Danish model of PBL, who cited him as a justification for their participant-directed, project-based approach to problem-orientation (Illeris, 1974).

\section{Karl Popper and the Role of Problems in the Growth of Knowledge}

Dewey was not the only philosopher to consider the role of problems in learning and inquiry. The Anglo-Austrian philosopher of science Karl Popper was also interested in problems, albeit from the perspective of scientific problem solving. Probably best known for his attempts to demarcate science for nonscience, Popper suggested that since nothing can ever be proven inductively, the best that science can do is to put forward hypotheses and theories and then attempt to falsify them (Popper, 1963). The best hypotheses are those that are the most resistant to falsification attempts-but they can never be held as eternal truths because the time may always come where their premises will be refuted through falsification. Therefore, anything that could not be subjected to a falsification test fell outside the remit of science. More importantly as concerns PBL, these scientific conjectures were content-bound: there was no stand-alone process of falsification without contextual and content-bound theories to support it. Indeed, problem solvers were engaged in a mental process, but these theories did not materialize from thin air: they were bound to a person's prior knowledge and understanding of the problem situation. Therefore, the role of problems was not to trigger some algorithmic process of problem solving but instead to prompt the 
formation of tentative theories explaining the underlying causes of the problem in the person's mind. These theories were then tested for errors and refined in confrontation with reality into better theories.

Popper's influence on PBL primarily came through the work of Henk Schmidt, particularly through the 1970s and 1980s. Schmidt saw in the Austrian philosopher's claims an explanation for the workings of $\mathrm{PBL}$, particularly as regards the activation of prior knowledge (Schmidt, 1983). This particular understanding of problem solving discredited the idea that PBL should be about learning a set of "problem-solving skills" or about "learning to learn" and paved the way for a more content-bound version of PBL. Being thus delivered of the concept of the tutorial as a mere exercise in "playing doctors" or practicing "clinical reasoning," PBL became instead an education method capable of tackling any content from any field. From there, in the 1980s, it broke free from its medical sphere of practice and entered other fields such as law, economics, and psychology.

\section{The Cognitive Revolution and Problem-Solving Skills}

The debate surrounding the content versus process of learning in PBL took a new turn following the "cognitive revolution" in psychology—-this movement, born in 1956, represented an attempted move away from the behaviorist paradigm that had dominated psychology since the 1930s (Miller, 2003). Cognitive psychology's principal contribution was the reinstatement of mental processes as the key to understanding human behavior and cognition, compounded with an attempt to understand the internal mechanisms through which the mind deals with information and knowledge (Bechtel, Abrahamsen, \& Graham, 2001). This quest for understanding led cognitive psychology to split in two distinct camps: on the one hand, those that believed that reasoning and problem solving were content-independent algorithmic processes that could be trained, known as "information processing psychology"; and on the other hand, those who believed that knowledge was the foundation of all reasoning and problem solving and therefore to improve problem-solving capacity, the knowledge base needed to be expanded, known as "constructivist psychology." The former were championed by artificial intelligence specialists Newell and Simon (1972). The latter drew inspiration from the works of early twentieth-century psychologists Piaget and Vygotsky, whose ideas were synthesized and adapted by Jerome Bruner, one of the founders of the cognitive revolution. Information processing psychology proposed that learning could best be understood as the improvement of the heuristics of problem solving, whereas constructivist psychology posited that learning should be seen as the "accommodation" (or change) of mental "schemas" (or representations). From the end of the 1970s, information processing psychology was discredited as no evidence was found to support its propositions regarding problem solving, leaving constructivist psychology as the sole surviving paradigm (Anderson, 1977).

This debate took center stage in PBL in the 1970s, a time during which Howard Barrows and Henk Schmidt conflicted on their views of the purpose of PBL. Barrows supported the information processing view, as evidenced by his views 
on PBL laid out in his book Problem-based learning: An Approach to Medical Education (Barrows \& Tamblyn, 1980), whereas Schmidt took the constructivist view (Schmidt, 1982). Although Schmidt, like Barrows, initially described PBL in terms of a hypothetico-deductive process (Schmidt, 1978), following the philosophy of science of Popper and the Gestalt psychologists, he later saw these hypotheses as content-laden theories by which students try to make sense of the problem and search for areas in which their prior knowledge falls short. The confrontation with emerging constructivist research (Anderson, 1977) led Schmidt to discard the problem-solving terminology altogether and adopt the view that PBL was about the construction of a knowledge base. The PBL problem served to activate prior knowledge, and the small-group discussion functioned as an opportunity to elaborate upon each other's knowledge (Schmidt, 1982).

The two views co-existed despite the lack of empirical support for information processing psychology, and spawned educational programs that, although both calling themselves "PBL," were built on fundamentally different learning principles (Schmidt, van de Molen, Te Winkel, \& Wijnen, 2009).

\section{Carl Rogers and Self-Directed Learning}

Carl Rogers was an American psychotherapist and educationist who pioneered the humanist psychology movement with his colleague Abraham Maslow in the 1950s and 1960s. Humanist psychology assumed that people, left to their own devices, would naturally tend to become the best version of themselves, or "selfactualize" through what they called "self-directed learning." This theory, which Rogers originally developed in the 1940s and 1950s in works such as ClientCentered Therapy (1951), was most prominently expressed in his book Freedom to Learn (1969), a collection of essays on education based on his experience as a psychology lecturer and psychotherapist. Rogers' thinking was derived from the existentialist philosophy of Kierkegaard, which regarded learning as a deeply personal achievement, encased in the phenomenal bubble of experience. This meant that, according to Rogers, a person could not be taught but had to experience the learning process in a deeply and personally meaningful way. Thus, teachers could not impart knowledge, but could only guide the learning process of the students as they wrestled with their experience and feelings. By the same token, curricula should not attempt to impose fixed learning schedules, modes of instruction, and, least of all, mandatory formal examinations. Instead, students should be free to choose what they would learn and how they would learn it, including ignoring the advice of their teachers. This Rogerian idea sprung from his understanding of the self and knowledge, whereby in an ever-changing world where information is outdated almost in the moment it surfaces, only the person is capable of grasping what is truly worth learning to him or her. The belief that people, given freedom, would naturally use it for self-improvement regardless of culture, age, or socioeconomic background sprang from the fundamental humanist tenet that human nature is good.

Of all of Rogers' ideas, "self-direction" has most lastingly impacted PBL. It first surfaced at McMaster in Dean Evans' founding memorandum, which called for 
"a self-directed learner, recognizing personal education needs, selecting appropriate learning resources and evaluating progress" (1966). This concept was restated as "zelfwerkzaamheid" (the ability to work through one's own drive) at Maastricht University, the world's second PBL program, when they proclaimed their basic philosophy (Basisfilosofie Achtste Medische Faculteit, 1972). Selfdirected learning has since been a core feature of all PBL programs; from this fundamental principle, nearly all other tenets of PBL could be derived from the guiding role of the tutor to the importance of self-study. However, some of the more extreme assumptions of Rogerian self-directed learning have been debunked as research has shown that the learning process is improved in PBL when the tutor has a content knowledge related role rather than a mere procedural role (Schmidt et al., 1993) and that examinations do improve the learning process in PBL (Norman et al., 2010).

\section{Further Developments in PBL: 1975-1990}

Over the years, PBL has spread to over 500 institutions (Moust, Bouhuijs, \& Schmidt, 2007) all over the world, in a vast array of academic disciplines. It would be impossible to cite all the ways in which PBL has developed since McMaster and Maastricht, so we have selected two particular trends: the emergence of problem-solving curricula and community-oriented programs.

\section{McMaster's Second Curriculum: Focus on Clinical Reasoning}

By 1977, calls for change grew at McMaster as the Spaulding curriculum was perceived to stifle innovation in education. This feeling was particularly strong among a group of young researchers and clinicians led by Dr. Vic Neufeld who had, unlike the founding fathers of McMaster, studied a Master in medical education at Michigan State University. This was a time where hypothetico-deductive ideas of cognitive psychology were in their prime, and Neufeld, supported by Barrows, brought to the table the idea that the training of clinical reasoning skills could be the center piece of a reformed curriculum at McMaster. The new curriculum, rolled out between 1977 and 1984, did away with the biomedical nature of the first curriculum and instead focused on priority healthcare problems-that is, introducing students to the healthcare problems most commonly seen in the community (MacDonald et al., 1989). The emphasis was no longer on understanding a basic set of underlying mechanisms, but on solving the problems at hand, in whichever direction the students deemed most appropriate. The chief objective of the Faculty of Medicine was revised to read: "to identify and define health problems at both an individual and a community level and to search for information to resolve or manage these problems" (Educational Committee, 1978). This was also the first time that, under Barrows' direction, the training of clinical skills came to the fore at McMaster, particularly through the use of simulated patients (Sutton, 1977). The shift of focus from knowledge acquisition to a greater emphasis on 
professional practice and the training of reasoning skills sparked the division between what Schmidt and colleagues called "mental model construction" (or Type 1) PBL curricula of the type practiced at Maastricht or McMaster between 1969 and 1977, and "process of inquiry" (or Type 2) PBL curricula of the type exemplified by the second McMaster curriculum (Schmidt et al., 2009).

The second McMaster curriculum was discontinued when the failure rate at the LMCC became alarming, and in 1993 was replaced once again by a Type 1 curriculum (Norman et al., 2010). However, and despite the fact that information processing psychology and hypothetico-deduction have fallen out of favor for 40 years, many PBL programs continue to use a Type 2 curriculum. These curricula tend to promote "problem-solving skills," "collaboration skills," and "learning to learn" as the chief benefits of PBL, often preferring to leave the acquisition of content to more traditional means of knowledge transfer. This has spawned a generation of "hybrid" programs in which students' time is divided between PBL and traditional lectures with anything ranging from less than $10 \%$ to more than $50 \%$ of their time allocated to PBL (Kwan \& Tam, 2009) - PBL in this instance often being used as some form of case study, or skills training class rather than the basis for acquiring new knowledge.

\section{Community-Orientation and the Network}

Another major variation on the PBL theme is the emergence of medical programs whose primary purpose was the development of community-oriented primary care physicians. These programs saw PBL as an instrument to give the priority health problems of the population at large a central position in the curriculum. One of the first among these was a program that emerged in 1979 at University New Mexico (Kaufman, 1985). At the time, New Mexico was rife with medically underserved remote rural communities, but medical students preferred to orientate themselves toward tertiary, specialized care in major cities and large hospitals rather than choose a career in primary care in the countryside. To remedy this, the founders of the program Drs. Kaufman and Obenshain had the idea that students should be sent out to the community during their medical education, but could not make this fit within a traditional medical curriculum. By chance, they met Barrows in 1977 and he convinced them to use PBL to bring their idea to life. Since New Mexico already had a medical school, they opened a separate "primary care track" for PBL, with a restricted number of students. The particularity of this curriculum was that unlike the McMaster and Maastricht programs, students spent the last 6 months of their first year of medical school in underserved communities, working with family physicians; the rest of the program ran much like the McMaster model. Kaufman reported in his 1985 retrospective that a larger number of the "primary care" cohort chose to stay in primary care compared with the regular medical track. Whether this was because the program was effective or because those who chose the program were already more inclined toward primary care remains to be seen.

The idea that PBL could be used to foster community-orientation was a powerful one and took off quite dramatically in the 1970s and 1980s. From Malaysia 
(Zabidi \& Fuad, 2002) to Nigeria (Bollag, Schmidt, Fryers, \& Lawani, 1982), on each continent of the world, community-oriented programmes emerged. The idea was so powerful that a "Network of Community-Oriented Educational Institutions for Health Sciences" was assembled under the auspices of the World Health Organization comprising almost 40 member schools, for which Maastricht long held the secretariat. The Network promoted conferences across the globe, the transfer of knowledge from institution to institution, and a number of publications evaluating the achievements of its members. These publications and conferences conflated PBL and community-orientation to a large extent, although community preceptorships are in no way necessarily bound together with PBL. Although the race to develop PBL curricula has slowed with many adopting hybrids instead, community-orientation remains popular in medical schools in developing countries.

\section{Alternative Developments: The Danish Project Model}

In the 1990s, a hitherto internationally unknown engineering program from Aalborg University in Denmark burst onto the PBL scene. Their commitment to PBL was such that in 2007 the United Nations Educational, Scientific and Cultural Organization (UNESCO) established a Chair for PBL in Engineering Education there (Kolmos, 2008), and in 2014, supervised the establishment of the Aalborg Centre for Problem Based Learning in Engineering Science and Sustainability under the auspices of UNESCO. Contrarily to all of the programs mentioned above, however, the emergence of the Aalborg phenomenon was not the result of the university's switch to a PBL curriculum of the McMaster or Maastricht type. On the contrary, the Aalborg educational model had been relatively stable since its establishment in 1974.

In the wake of the student revolt of 1968 in Copenhagen, the Danish parliament approved the establishment of two university centers whose pedagogy would be radically different to the traditional, professor-centered programs of the established Danish universities (Whitehead, 2007). The first was opened in Roskilde, $30 \mathrm{~km}$ outside Copenhagen, in 1972, and the second was Aalborg, $300 \mathrm{~km}$ away in the northern-most province of Denmark. Both institutions shared similar instructional principles: problem-orientation, participant direction, and interdisciplinarity bound together in project work (Berthelsen, Illeris, \& Poulsen, 1977; Illeris, 1974). In its conception, this model was different from more application-oriented forms of project work common to many vocational studies such as architecture or agriculture in that the starting point of the learning should be a social problem from which theory and knowledge should be derived in a way relevant to practice (Roskilde Universitetcenter, 1972). The specific problem should also give access to the broader perspective on the subject, a principle borrowed from the German philosopher Oskar Negt and dubbed exemplarity (Negt, 1971). Key features of this model were that, first, responsibility for problem-formulation was a joint venture between students and teachers rather than teachers alone (Illeris, 1974); second, problems were not tackled in short week-long cycles like at Maastricht, but in semester-long projects usually 
done in groups of six to eight students (Aalborg Universitetscenter, 1976); third, although this was not the original intention, regular courses were an integral part of the model, the usual split being 50\% project work and 50\% coursework (Enemark \& Kjaersdam, 1994).

Beyond these commonalities, the model developed in a somewhat fractious manner. First, there was a split between Roskilde and Aalborg: Roskilde University was founded as a dream project of the Danish Student Union, fed by radical teachers from Copenhagen and the neo-Marxist ideal of fagkritik, or the critical analysis of disciplines (Hansen, 1997). Aalborg University on the other hand was the product of years of lobbying from regional interest groups who longed to see a university in Northern Jutland, and although it also attracted a fair share of radical elements, this was not its defining characteristic (Clausen, 1984). Second, within Aalborg itself, there was a split of ambitions between the humanities and social sciences on the one hand, and the natural and technical sciences on the other: the former was to some extent concerned with social critique, while the latter was concerned with building the credibility of its model vis $\grave{a} v i s$ other engineering institutions in Denmark, and thus, there was no coherent application of the educational model across the board (Kolmos et al., 2004; Whitehead, 2007).

Perhaps as a consequence of its desire for credibility on the international education scene, Aalborg's former Dean of Engineering Finn Kjaersdam moved to have the Aalborg model renamed to "problem-based learning" during his rectorship of the university in the 1990s. This move was accompanied by some soulsearching to determine whether project work could indeed be considered a part of the PBL family (Kolmos, 1996). By the 2000s, the adoption of the PBL terminology was complete and self-evident for Aalborg, which began releasing publications in which the distinction was either only briefly mentioned or no longer made (De Graaff \& Kolmos, 2003). At the time of writing, researchers from the Aalborg model intermingle at conferences and in publications with those from the medical model and a whole host of hybrids, variations, and iterations of PBL across disciplines and types of education. It should be noted that Roskilde never partook in the PBL renaming, choosing instead to use the acronym PPL with emphasis on its critical heritage. Whether this serves to broaden the definition of PBL to a hold-all umbrella of progressive education methods or just creates a situation where different understandings of PBL co-exist confusingly remains to be seen.

\section{Conclusion}

The primary conclusion to draw from this brief intellectual history of PBL is that the advent and development of PBL has not been a smooth and straightforward process - it was a patchwork of borrowed innovations and diffuse understandings of various education philosophies set in a time where change and reform were in the air. For that reason, perhaps, it became a rather plastic terminology, able to envelope different interpretations of the model, as subtle as the changes made by Maastricht or far reaching as the adoption of the name "PBL" by Aalborg. 
For that reason also, it has been the stage for numerous intellectual disputes over the purpose and principles that underlie it. If history is not able to hand us a definitive answer to the question: "what is PBL," then this question must be handled either bottom-up by psychology, to determine through experimentation and data, or top-down by philosophy to determine through definitive principles, though some might argue that the result in either case would amount to little more than a more consensual construction of the term. The question of whether a plastic catchall terminology is preferable to a strictly defined one is a whole other matter.

\section{References}

Aalborg Universitetscenter (1976). Aalborg Universitetscenter aarsberetning. Aalborg, Denmark: Aalborg Universitetscenter.

Ad Hoc Committee on Undergraduate Education. (1969, September 24). Summary of Report of the Ad Hoc Committee on Undergraduate Education-Presented to the Council of the Faculty of Medicine, September 24, 1969. 232.5;5. Hamilton, ON: Educational Programme Committee-McMaster University HHS/FHS Archives.

Anderson, R. (1977). The notion of schemata and the educational Enterprise: General discussion of the conference. In R. Anderson, R. Spiro, \& W. Montague (Eds.), Schooling and the acquisition of knowledge (pp. 415-431). Hillsdale, NJ: Lawrence Erlbaum.

Apple, M. W., \& Teitelbaum, K. (2001). John Dewey, 1859-1952. In J. A. Palmer (Ed.), Fifty major thinkers on education - From Confucius to Dewey (Kindle ed. (pp. 177-182). New York, NY: Routledge.

Barrows, H. S. (1968). Simulated patients in medical teaching. Canadian Medical Association Journal, 39, 674-676.

Barrows, H. S. (1996). In memoriam: James E. Anderson, MD. Teaching and Learning in Medicine, 8(1), 61.

Barrows, H. S., \& Neufeld, V. R. (1974). The "McMaster Philosophy": An approach to medical education. Journal of Medical Education, 49, 1040-1050.

Barrows, H. S., \& Tamblyn, R. M. (1980). Problem-based learning. New York, NY: Springer Pub Co.

Basisfilosofie Achtste Medische Faculteit. (1972). Medische Contact, 27, 879-884.

Bechtel, W., Abrahamsen, A., \& Graham, G. (2001). Cognitive science, history. In International encyclopedia of the social and behavioural sciences (pp. 2154-2158). Oxford, England: Elsevier Science.

Berthelsen, J., Illeris, K., \& Poulsen, S. C. (1977). Projektarbejde: erfaringer og praktisk vejledning. Holsebro, Denmark: Borgen.

Bollag, U., Schmidt, H., Fryers, T., \& Lawani, J. (1982). Medical education in action: Community-based experience and service in Nigeria. Medical Education, 16(5), 282-289.

Cannon, W. B. (1900). The case method of teaching systematic medicine. Boston Medical and Surgical Journal, 142(1), 31-36. 
Clausen, A. (1984). Kampen for et nordjysk universitet (1st ed.). Aalborg, Denmark: Aalborg Universitetsforlag.

Cohen, M. J., \& Crombag, H. F. (1978). De nieuwe medische faculteit in Maastricht en de juridische opleiding. Nederlandse juristenblad, 19, 355-362.

De Graaff, E., \& Kolmos, A. (2003). Characteristics of problem-based learning. International Journal of Engineering Education, 19(5), 657-662.

Dewey, J. (1933). How we think (2nd ed.). Lexington, MA: Heath and Company.

Dewey, J. (1916/2011). Democracy and education. Milton Keynes, England: Simon and Brown.

Dickinson, C. (1970, July 29). Re: Cardiovascular Phase III - To: C.J. Schwartz. 232.5;8. Hamilton, ON: Educational Programme Committee-McMaster University FHS/HHS Archives.

Educational Programme Committee. (1968). Phase I Programme: 1969. 232.4;4. Hamilton, ON: Educational Programme Committee-McMaster University FHS/ HHS Archives.

Educational Programme Committee. (1978). Objectives of the M.D. Programme (Revised). 233.2;4. Hamilton, ON: Educational Programme Committee-McMaster University FHS/HHS Archives.

Enemark, S., \& Kjaersdam, F. (1994). The Aalborg experiment: Project Innovation in university education. Aalborg, Denmark: Aalborg University Press.

Evans, J. (1966). General objectives. 145.8;1. Hamilton, ON: Objectives of the Faculty School of Medicine-McMaster University HHS/FHS Archives.

Flexner, A. (1910). Medical education in the United States and Canada: a report to the Carnegie Foundation for the Advancement of Teaching (No. 4). Carnegie Foundation for the Advancement of Teaching.

Fraser, C. (1931). The case method of instruction: A related series of articles. New York, NY: McGraw-Hill Books Company Inc.

Garvin, D. A. (2003). Making the case. Harvard Magazine, 106(1), 56-65.

Hamilton, J. D. (1976). The McMaster curriculum: A critique. The British Medical Journal, 6019(1), 1-7.

Hansen, E. (1997). En koral I tidens strøm. Frederiksberg, Denmark: Roskilde Universitetsforlag.

Hergenhahn, B. R. (2001). An introduction to the history of psychology (4th ed.). Belmont, CA: Wadsworth/Thomson Learning.

Hillen, H., Scherpbier, A., \& Wijnen, W. (2010). History of problem-based learning. In H. V. Berkel, A. Scherpbier, H. Hillen, \& C. V. Vleuten (Eds.), Lessons from problem-based learning (pp. 5-12). New York, NY: Oxford University Press.

Horizontal Programme Planning Committee. (1968). Interim Report. 232.4;7. Hamilton, ON: Educational Programme Committee-McMaster University FHS/ HHS Archives.

Illeris, K. (1974). Problemorientering og deltagerstyring: oplag til en alternativ didaktik (1st ed.). Copenhagen, Denmark: Munskgaard.

Kaufman, A. (1985). Implementing problem-based medical education. New York, NY: Springer Pub. Co.

Kimball, B. A. (1995). Emergence of the case method of teaching, 1870s-1990s. Bloomington, IN: The Poynter Center, Indiana University. 
Knegtmans, P. J. (1992). De medische faculteit Maastricht: een nieuwe universiteit in een herstructureringsgebied, 1969-1984. Assen, The Netherlands: Van Gorcum.

Kolmos, A. (1996). Reflections on project work and problem-based learning. European Journal of Engineering Education, 21(2), 141-148.

Kolmos, A. (2008). UNESCO chair in problem-based learning in engineering education. Aalborg, Denmark: UNITWIN/UNESCO Chairs Programme.

Kolmos, A., Fink, F. K., \& Krogh, L. (2004). The Aalborg model-Problem and project based learning. In A. Kolmos, F. K. Fink, \& L. Krogh (Eds.), The Aalborg PBL Model: Progress, diversity and challenges (pp. 9-18). Aalborg, Denmark: Aalborg University Press.

Kraemer, J. D. (1968a, November 31). Joint meeting of Phase III and Education Committees. 232.4;6. Hamilton, ON: Educational Programme CommitteeMcMaster University FHS/HHS Archives.

Kraemer, J. D. (1968b). Re: The Problem-Solving Problem. 232.4;6. Hamilton, ON: Education Committee Minutes-McMaster University FHS/HHS Archives.

Kraemer, J. D. (1969a, March 28). Education Committee Meeting-March 28, 1969. 232.5;1. Hamilton, ON: Education Programme Committee-McMaster University FHS/HHS Archives.

Kraemer, J. D. (1969b, March 28). Education Committee Meeting-March 3, 1969. 232.5;1. Hamilton, ON: Education Programme Committee-McMaster University FHS/HHS Archives.

Kwan, C. Y., \& Tam, L. (2009). Hybrid PBL-What is in a name? Journal of Medical Education, 13(3), 76-82.

Ludmerer, K. M. (2010). Commentary: Understanding the Flexner report. Academic Medicine, 85(2), 193-196.

MacDonald, P. J., Chong, P. J., Chongtrakul, P., Neufeld, V. R., Tugwell, P., Chambers, L. W., ... Oates, M. J. (1989). Setting educational priorities for learning the concepts of population health. Medical Education, 23, 429-439.

McAuley, J. (1978, October 25). McMaster Oral History-Dr. W.B. Spaulding. Hamilton, ON: McMaster University FHS/HHS Archives.

McAuley, J. (1979, September 28). McMaster Oral History - Dr. J.R. Evans. 145.8;1. Hamilton, ON: McMaster University HHS/FHS Archives.

Miller, G. A. (2003). The cognitive revolution: A historical perspective. Trends in Cognitive Sciences, 7(3), 141-144.

Moore, W. (1968). The tutorial system and its future (1st ed.). New York, NY: Pergamon Press.

Moust, J., Bouhuijs, P., \& Schmidt, H. (2007). Introduction to problem-based learning: A guide for students. Groningen, The Netherlands: Wolters-Noordhoff.

Mueller, C. B. (2008). McMaster University Medical School: The little school that could-And did. McMaster Medical Journal, 5(1), 29-33.

Mustard, J. F. (1968). Objectives of the Faculty of Medicine-Letter to D.L. Sackett-11th November 1968. 145.8;1. Hamilton, ON: McMaster University HHS/FHS Archives.

Negt, O. (1971). Soziologische phantasie und exemplarishes lernen: Zur theorie und praxis der Arbeiterbildung. Frankfurt am Main, Germany: Europaïsche Verslagsanstalt. 
Newell, A., \& Simon, H. (1972). Human Problem Solving. Englewood Cliffs, NJ: Prentice-Hall.

Norman, G. R., Neville, A., Blake, J. M., \& Mueller, C. B. (2010). Assessment steers learning down the right road: Impact of progress testing on licensing examination performance. Medical Teacher, 32, 496-499.

Palfreyman, D. (2001). The Oxford tutorial: "Thanks, you taught me how to think". Oxford, England: Oxford Centre for Higher Education Policy Studies.

Popper, K. (1963). Conjectures and refutations, the growth of scientific knowledge. New York, NY: Routledge.

Projektgroep tutorensysteem. (1979). Letter to the chairman of the department of the faculty of medicine RL. Rotterdam, The Netherlands: Erasmus University Rotterdam, Archive Collection of H.G. Schmidt.

Rogers, C. R. (1969). Freedom to learn. Columbus, OH: C. E. Merrill Pub. Co. Roskilde Universitetcenter. (1972). Betænkning Om Samfundsvidenskabelig Basisuddannelse. Mag RHS a 183. Roskilde, Denmark: Roskilde University Library, RU-History collection.

Schmidt, H. G. (1977a). Hoofdprojekt onderzoek van onderwijs. OC77-249. Maastricht, The Netherlands: Rijksarchief in Limburg-07.C06-inventaris 95.

Schmidt, H. G. (1977b). Voorstel tot het opstarten van een projekt "tutorsysteem". Kursus Probleemgeorienteerd Onderwijs. OC 78-116. Maastricht, The Netherlands: Rijksarchief in Limburg 07.C06-Inventaris 98.

Schmidt, H. G. (1978). Probleem-georiënteerd onderwijs: leren aan de hand van problemen. Meta, 1, 4-15.

Schmidt, H. G. (1982). Activatie van voorkennis, intrinsieke motivatie en de verwerking van tekst. Appeldoorn, The Netherlands: Van Walraven.

Schmidt, H. G. (1983). Problem-based learning: Rationale and description. Medical Education, 17, 11-16.

Schmidt, H. G. (1993). Foundations of problem-based learning: Some explanatory notes. Medical Education, 27(5), 422-432.

Schmidt, H. G. (2012). A brief history of problem-based learning. In G. O'Grady, E. H. Yew, K. P. Goh, \& H. G. Schmidt (Eds.), One-day, one-problem, an approach to problem-based learning (pp. 21-40). Singapore: Springer Science + Business Media.

Schmidt, H. G., \& Bouhuijs, P. A. (1980). Onderwijs in taakgerichte groepen. Utrecht, The Netherlands: Spectrum.

Schmidt, H. G., Arend, A., Moust, J. H., Kokx, I., \& Boon, L. (1993). Influence of tutors' subject-matter expertise on student effort and achievement in problembased learning. Academic Medicine, 68(10), 784-791.

Schmidt, H. G., Majoor, G., \& Wijnen, W. H. (1979). Introduction to the medical study. Maastricht, The Netherlands: Onderwijsreeks Rijksuniversiteit Limburg.

Schmidt, H. G., van de Molen, H., Te Winkel, W. W., \& Wijnen, W. H. (2009). Constructivist, problem-based learning does work: A meta-analysis of curricular comparisons involving a single medical school. Educational Psychologist, 44(4), 227-249.

Servant, V. F. (2016). Revolutions and re-iterations, an intellectual history of problem-based learning (Unpublished doctoral thesis ed.). Rotterdam, The Netherlands: Eramus University Rotterdam. 
Spaulding, W. B. (1967). Visit to Western University School of Medicine, May 15th and 16th, 1967. 232.4;1. Hamilton, ON: Educational Programme CommitteeMcMaster University FHS/HHS Archives.

Spaulding, W. B. (1968). The Undergraduate Medical Curriculum: McMaster University. 145.8;1. Hamilton, ON: McMaster University, Objectives of the Faculty School of Medicine, FHS/HHS Archives.

Spaulding, W. B. (1991). Revitalizing medical education, McMaster medical school the early years 1965-1974. Hamilton, ON: Decker Inc.

Sutton, J. (1977, November 15). To: Dr. G.S. Cameron - November 15, 1977. 233.2;3. Hamilton, ON: Educational Programme Committee-McMaster University FHS/ HHS Archives.

Thode, H. (1963). Report and recommendations regarding a medical school at McMaster University. 144.2;1. Hamilton, ON: McMaster University, Accreditation Preparation Visit, FHS/HHS Archives.

Whewell, W. (1858). History of inductive sciences (3rd ed.). New York, NY: Appleton and Company.

Whitehead, J. S. (2007). Denmark's two university centres: The quest for stability, autonomy and distinctiveness. Higher Education, 10(1), 89-101.

Wijnen, W. H. (1976). Evaluatie van Studieresultaten. OC 76-059. Maastricht, The Netherlands: Rijksarchief in Limburg-07.C06-inventaris 90.

Williams, G. (1980). Western Reserve's experiment in medical education and its outcomes. New York, NY: Oxford University Press.

Zabidi, H., \& Fuad, A. R. (2002). Medical education in Universiti Sains Malaysia. The Medical Journal of Malaysia, 57, 8-12. 